Thorax (1965), 20, 53.

\title{
Unexplained underventilation of the lungs
}

\author{
MARTIN W. MCNICOL AND N. B. PRIDE \\ From the Department of Medicine, Hammersmith Hospital, London W.12
}

The lungs normally are ventilated with enough air to dilute the carbon dioxide produced by metabolism, so that the partial pressure of carbon dioxide $\left(\mathrm{PCO}_{2}\right)$ in the alveoli is kept remarkably close to $40 \mathrm{~mm}$. $\mathrm{Hg}$. It is the alveolar ventilation and not the total amount of air going in or out of the mouth (or 'minute-volume') that determines the $\mathrm{PCO}_{2}$ because a varying proportion of the total ventilation goes to the dead space and takes no part in gas exchange. Alveolar ventilation will be inadequate when total ventilation is reduced but will also be inadequate when there is normal or even increased total ventilation if dead space ventilation is increased. Such an increase in dead space ventilation will occur if breathing is rapid and shallow and mainly into the upper anatomical dead space, or if there is ventilation of alveoli poorly supplied with blood. Little gas exchange takes place in poorly perfused alveoli, so that these alveoli can be regarded as additional 'functional' dead space. In all cases inadequacy of alveolar ventilation will result in a rise in alveolar $\mathrm{PCO}_{2}$; and because of the high diffusibility of carbon dioxide the arterial and alveolar $\mathrm{PCO}_{2}$ are virtually identical so that the arterial $\mathrm{PCO}_{2}$ will also be increased.

\section{CAUSES OF UNDERVENTILATION}

Chronic alveolar underventilation has numerous causes which may be grouped as follows:

ABNORMALITY OF LUNGS OR THORACIC CAGE Underventilation may occur with any condition which impairs ventilatory capacity, and most commonly this impairment is due to airways obstruction, as in chronic bronchitis. It has been suggested that in patients with severe airways obstruction the respiratory centre becomes insensitive to carbon dioxide (Prime and Westlake, 1954), but more recent work (Cherniack and Snidal, 1956; Richards, Fritts, and Davis, 1958) suggests that the impaired movement of the chest and lungs as bellows and the increased alveolar dead space are sufficient to account for

1 Present address : Central Middlesex Hospital, London, N.W.10 2 Present address : Cardiovascular Research Institute, University of California Medical Center, San Francisco 22 carbon dioxide retention without postulating impaired sensitivity to carbon dioxide. Some cases of underventilation occur with a restrictive impairment of ventilatory capacity, such as kyphoscoliosis or pleural thickening, and underventilation may also occur when there is neuromuscular weakness, as in myasthenia gravis, motor neurone disease, or spinal poliomyelitis. All this common group have an impaired ventilatory capacity.

DISEASE OF THE CENTRAL NERVOUS SYSTEM There have been reports of underventilation in bulbar poliomyelitis (Sarnoff, Whittenberger, and A.ffeldt, 1951), after encephalitis (Efron and Kent, 1957; Garlind and Linderholm, 1958), and in bulbar syringomyelia (case 4 of Rodman, Resnick, Berkowitz, Fennelly, and Olivia, 1962), but these causes are all uncommon. Underventilation may also occur after the administration of drugs which depress the central nervous system. In this group the ventilatory capacity is not reduced.

OBESITY Since 1951 there have been numerous reports of underventilation in extremely obese patients; sometimes there has been some reduction in lung volumes and ventilatory capacity but this is usually slight.

UNEXPLAINED In 1959 Rodman and Close reviewed four previous reports (Ratto, Briscoe, $\mathrm{N}$ orton, and Comroe, 1955; Massachusetts General tospital, 1956; Pare and Lowenstein, 1956; Kichter, V est, and Fishman, 1957) and described a fifth case in which there was underventilation in subjects of normal weight and without abnormality of the thoracic cage or lungs. This they called the "primary hypoventilation syndrome'. Since then $\mathrm{t}$ adorn and Scherrer (1959), Lawrence (1959), Naeye (1961), and Rodman et al. (1962) have reported a further five cases. It is possible that the fifth patient of Newman, Feltman, and Devlin (1951), who was described as 'moderately obese', was another example.

During the last two years we have seen four patients, not grossly obese, who had chronic 
alveolar underventilation not adequately explained by their lung disease. They form an interesting group who tended to have periods of drowsiness and episodes of apnoea. We here report their case histories and the results of some lung function tests to show how this condition may be distinguished from 'chronic bronchitis and emphysema' with which it can easily be confused.

\section{CASE REPORTS}

CASE 1 C.P., a 53-year-old policeman, had been overweight (90 to $100 \mathrm{~kg}$.) from the age of 45 years. In December 1956 he was seen by Dr. M. O. J. Gibson at the Bow Arrow Hospital as a contact of a case of pulmonary tuberculosis. His only symptom then was a mild morning cough but he was noted to be polycythaemic (haemoglobin 19.2 g./100 ml.). A chest radiograph showed no sign of tuberculosis but there was a shadow at the right lower hilum which appeared on tomography to be an aneurysmal dilatation of the right lower lobe pulmonary artery. In June 1957 he had acute bronchitis and a comment was made on his 'astonishing cyanosis'. He was admitted to the Bow Arrow Hospital in November 1957 with a further attack of acute bronchitis. Though his dyspnoea was only slight the acute bronchitis was followed by the rapid onset of right heart failure with gross oedema. He was observed to be drowsy and admitted to undue sleepiness $\stackrel{\overrightarrow{\vec{\rho}}}{\overrightarrow{2}}$ and nocturnal sweating in the preceding year.

On examination the hands were warm and there waso음 central cyanosis. The pulse was regular and the bloodon pressure $110 / 85 \mathrm{~mm} . \mathrm{Hg}$; there was oedema of the legs $\widehat{\Phi}$ and over the sacrum. The jugular venous pressure was raised, and the pulse wave showed a prominent ' $a$ ' wave.cs A prominent right ventricular impulse was palpable, $\vec{\circ}$ and there was accentuation of the pulmonary component of the second sound and a loud right atrial sound but no $\vec{\omega}$ murmurs. A few crepitations were present at both lung bases. There was no abnormality in the central nervous $\vec{x}$ system.

Investigations The haemoglobin was $17.8 \mathrm{~g} . / 100 \mathrm{ml} .--$ A chest radiograph showed large pulmonary arteries ${ }_{\omega}^{j}$ and an increased right hilar shadow with an enlargedo right ventricle (see Fig. 1). There was right axis deviation, $P$ pulmonale and evidence of right ventricular hypertrophy on the electrocardiogram. Arterial blood analysises showed an oxygen saturation of $72 \%$ and a raised carbon dioxide content, but no measurement was made of the $\mathrm{PCO}_{2}$.

It was concluded that he had emphysema with chronic $\overrightarrow{\mathscr{g}}$ respiratory failure and cor pulmonale. The heart failure responded to digoxin and mersalyl and he remainedo relatively well except for a bout of paroxysmal tachycardia with anginal pain in February 1958 and two further attacks of acute bronchitis in March 1958 and January 1959. In July 1959 he was admitted to Hammer-요

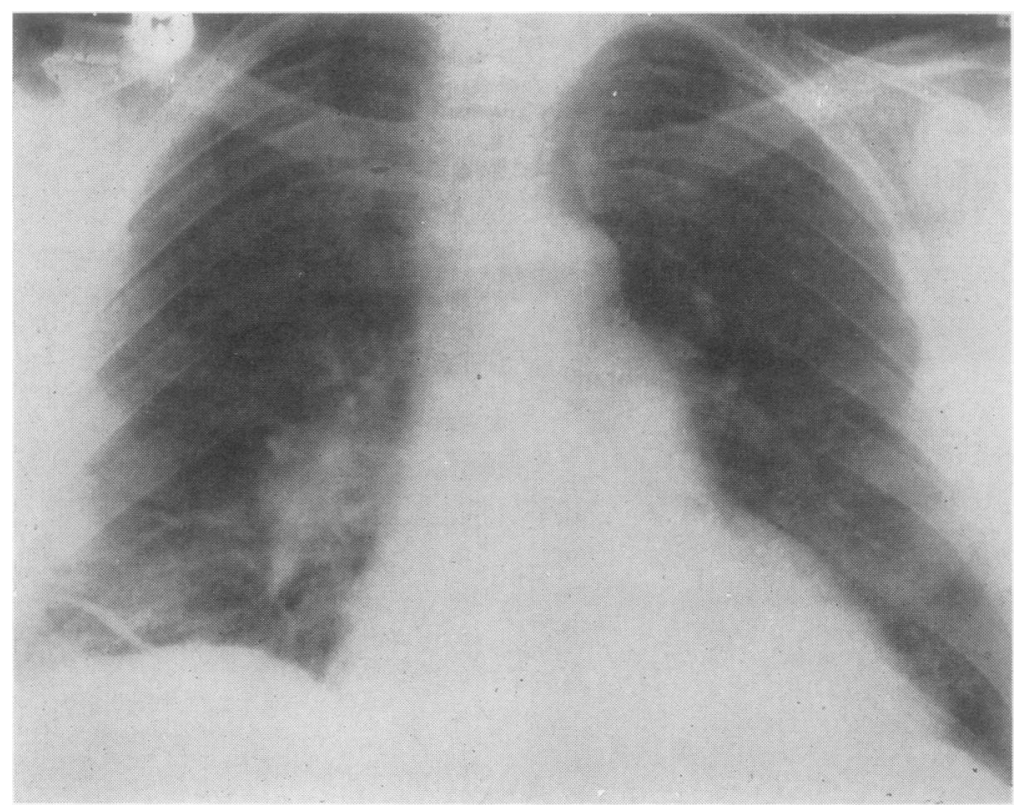

FIG. 1. Case 1. Postero-anterior chest radiograph showing an enlarged heart, large main pulmonary arteries, and an opacity at the lower part of the right hilum. 
smith Hospital with a recurrence of right heart failure; dyspnoea was still slight.

Examination showed no change in the physical signs.

Further investigations then revealed a red blood cell volume of $7,000 \mathrm{ml}$. and a plasma volume of $3,400 \mathrm{ml}$. At this time the haemoglobin was $21 \mathrm{~g} . / 100 \mathrm{ml}$. and the white blood cell and platelet counts were normal. The venous plasma total carbon dioxide content $\left(\mathrm{TCO}_{2}\right)$ was $38 \mathrm{mM}$./l., and arterial blood analysis showed that the oxygen saturation was $74 \%$, the $p \mathrm{H}$ was $7 \cdot 29$, and the $\mathrm{PCO}_{2} 80 \mathrm{~mm}$. Hg.

He again responded to digoxin and mersalyl. As his oedema-free weight was $97 \mathrm{~kg}$. he was placed on a reducing diet.

In October 1959 he had a further attack of acute bronchitis followed within 24 hours by gross underventilation and coma. On admission he was very deeply cyanosed and was sweating profusely, and there was widespread muscle twitching. Heart failure had not recurred. An intravenous infusion of nikethamide was started and tracheostomy was performed; oxygen and antibiotics were given and digoxin and mersalyl were continued. He made a rapid recovery. Nine days later, however, there was a further sudden episode of virtual apnoea and coma; this relapse was not associated with infection. The tracheostomy was re-opened and a further nikethamide infusion was given, but there was little response and he required intermittent positive pressure respiration from a Radcliffe respirator for the next four days. He again recovered and was reasonably well until April 1960 when he had a recurrence of right heart failure. In October 1960 he had an episode of syncope on effort. In December 1960 he had a left basal pulmonary infarct and was noted to have an ill-sustained nystagmus on looking to the right; this sign disappeared within a week and at no other time have there been abnormal neurological signs. In January 1962 he had a right lower lobe pneumonia, a recurrence of heart failure, and a left femoral vein thrombosis. Clubbing of the fingers and toes, previously absent, had developed. On three occasions during this illness he became very drowsy but responded to intravenous infusion of nikethamide. $\mathrm{He}$ remains chronically cyanosed and has a mixed venous $\mathrm{PCO}_{2}$ between 80 and $95 \mathrm{~mm}$. $\mathrm{Hg}$ (the normal value is less than $54 \mathrm{~mm} . \mathrm{Hg}$ ) despite which he feels relatively well and remains at work. A pulmonary systolic murmur has appeared, but the opacity at the right hilum on the chest radiograph has remained unchanged over the last five years.

Treatment Treatment has been directed to correcting the heart failure, obesity, polycythaemia, and underventilation.

The heart failure has responded well to digoxin and mersalyl.

His weight was reduced by $9 \mathrm{~kg}$. to $88 \mathrm{~kg}$. without a change in the $\mathrm{PCO}_{2}$.

The polycythaemia was at first treated by repeated venesection but by April 1960 he had a mild iron deficiency anaemia with a grossly elevated packed cell volume (P.C.V.) and he was treated with radioactive phosphorus $\left(6 \mathrm{mc}{ }^{32} \mathrm{P}\right)$ and oral iron. A further dose of ${ }^{32} \mathrm{P}$ was given in December 1960 . The haemoglobin and P.C.V. have been reduced but are still above normal.

It was thought that thrombosis in the right lower pulmonary artery associated with the polycythaemia might have accounted for the radiological opacity but no local alteration in blood flow was shown by regional studies using radioactive gases. In addition he has had a probable left external jugular vein thrombosis, a pulmonary infarct, and a femoral vein thrombosis. For these incidents he has been treated with phenindione and is now being maintained on long-term anticoagulant treatment. Treatment of the polycythaemia has not reduced the $\mathrm{PCO}_{2}$.

Many central nervous system stimulants and respiratory stimulants have been tried but only nikethamide has been of benefit. Five intravenous infusions of nikethamide have been given. On two occasions tracheostomy was also performed; the other three infusions of doses between 25 and $40 \mathrm{mg}$./minute resulted in improvements in consciousness and sustained falls of mixed venous $\mathrm{PCO}_{2}$ of 9, 26, and $19 \mathrm{~mm}$. $\mathrm{Hg}$. No reduction in $\mathrm{PCO}_{2}$ followed maintained oral treatment with caffeine, dexamphetamine, salicylates, amiphenazole, or the carbonic anhydrase inhibitors, acetazolamide and dichlorphenamide. He proved a resistant subject to hypnosis, and daily periods of voluntary overventilation did not help. With intermittent positive pressure respiration (I.P.P.R.) by a Radcliffe respirator the mixed venous $\mathrm{PC}_{2}$ was maintained at 50 to $55 \mathrm{~mm}$. $\mathrm{Hg}$ for several days, but, despite gradual weaning, the $\mathrm{PCO}_{2}$ soon regained its former level of over $80 \mathrm{~mm}$. when I.P.P.R. was discontinued. An attempt at I.P.P.R. with a patient-triggered apparatus failed to increase the ventilation as he closed his glottis against the machine.

CASE 2 A. A., a 56-year-old master bricklayer (this case is being reported in more detail elsewhere by Dr. V. Wynn), was first seen at St. Mary's Hospita! at the age of 51 when he complained of breathlessness on effort. He admitted to cough and phlegm for several years but had not noticed the gross ankle oedema then present. He was obese $(95 \mathrm{~kg}$.). The family history of obesity was striking; his father was about $95 \mathrm{~kg}$. and died of heart failure, and his mother weighed $140 \mathrm{~kg}$. The patient has five brothers and two sons and all of these are heavier than he but without symptoms. Despite the right heart failure, the heart sounds then were normal and there were no murmurs. A diagnosis of cor pulmonale on a basis of chronic bronchitis and emphysema exacerbated by obesity was made and he made an excellent response to mersalyl and a low salt and low calorie diet. In January 1957 he was free of all symptoms except cough. There were no abnormal signs on examination and his weight had fallen $7 \mathrm{~kg}$. to $88 \mathrm{~kg}$.; but the haemo-

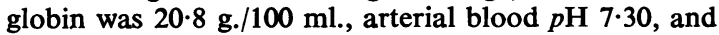
$\mathrm{PCO}_{2} 69 \mathrm{~mm}$. Hg. In January 1958 he had an attack of acute bronchitis followed by heart failure, and this sequence of events recurred in March 1959; each episode responded well to antibiotics, digoxin, and diuretics. He was well and at work until November 1960 when 
heart failure recurred. On recovery from this some further investigations were made at Hammersmith Hospital in December 1960.

Examination then showed moderate obesity $(78 \mathrm{~kg}$.). There was no clubbing. The only abnormalities in the cardiovascular system were accentuation of the pulmonary component of the second sound and a grade 2 systolic murmur, increasing on inspiration, at the left sternal edge. The blood pressure was $90 / 60 \mathrm{~mm}$. $\mathrm{Hg}$ and no abnormalities were found in the rest of the examination.

Investigations The haemoglobin was $17 \mathrm{~g} / 100 \mathrm{ml}$. with a packed cell volume of $53 \%$. The venous plasma total carbon dioxide content was $36 \mathrm{mM}$. 1 . A chest radiograph showed a large heart and main pulmonary arteries. There was incomplete right bundle branch block on the electrocardiogram.

Course His weight has been reduced by $17 \mathrm{~kg}$. in the last five years but the $\mathrm{PCO}_{2}$ has always been abnormal except for a period when he was treated with dichlorphenamide.

CASE 3 L. W.. a 51-year-old painter and decorator, had developed at the age of 40 a winter cough with frequent episodes of purulent sputum. For seven years he had noticed slight but slowly progressing dyspnoea of effort. He had had no ankle swelling. For at least four months he had had frequent but mild headaches. On direct questioning he admitted to undue drowsiness and frequent night sweats during the past year.

On 10 November 1960 he was found unconscious at home and was admitted to the Central Middlesex Hospital under the care of Dr. R. Asher. He was then semiconscious and cyanosed and had early papilloedema; lumbar puncture revealed a normal cerebrospinal fluid at a pressure of $230 \mathrm{~mm}$. $\mathrm{H}_{2} \mathrm{O}$. The mixed venous $\mathrm{PC}_{2}$ was $75 \mathrm{~mm}$. $\mathrm{Hg}$. In the next few days he complained of headache and he had several further episodes in which apnoea was followed by coma. He invariably recovered from these episodes when given intravenous nikethamide. After 10 days he had no further episodes of coma nor any headache. The papilloedema regressed completely and the only abnormal finding remaining in the central nervous system was diplopia on looking to the left and upwards. An electrocardiogram showed non-specific changes; bilateral carotid angiography was normal. The mixed venous $\mathrm{PCO}_{2}$ however remained persistently high.

He was admitted to Hammersmith Hospital for investigation in early January 1961; his only complaint then was of diplopia.

On examination there was no cyanosis or clubbing. He weighed $80.5 \mathrm{~kg}$. The blood pressure was $150 / 80$ $\mathrm{mm}$. $\mathrm{Hg}$ and no abnormality was found in the cardiovascular system. The sputum was mucopurulent and there were occasional basal wheezes. There was weakness of the left medial rectus, superior oblique, and inferior oblique muscles.

Investigations The haemoglobin was $15 \cdot 1 \mathrm{~g} . / 100 \mathrm{ml}$. with a packed cell volume of $51 \%$. The venous plasma urea and electrolytes were normal except for a total carbon dioxide content of $33 \mathrm{mM}$. There was patchy consolidation in the right middle and lower zones on the chest radiograph but no increase in heart size. An electrocardiogram showed slight clockwise rotation but no evidence of right ventricular hypertrophy. An electroencephalogram was normal but the mixed venous $\mathrm{PCO}_{2}$ was still raised to $60 \mathrm{~mm}$. $\mathrm{Hg}$.

Course In the 18 months since first being seen he has had no further episodes of coma and has returned to work. The mixed venous $\mathrm{PCO}_{2}$ varies between 50 and $59 \mathrm{~mm} . \mathrm{Hg}$; nevertheless, although he was quite free of symptoms when he was seen as an out-patient in September 1961, he still rapidly became cyanosed on exercise and was able to hold his breath for one and three quarter minutes without discomfort but with the development of cyanosis. The diplopia has resolved and no other neurological signs have developed. It seemed probable that the episodes of coma had been precipitated by acute underventilation with consequent hypoxia, $\mathrm{CO}_{2}$ retention, and acidaemia.

CASE 4 W. N., a 48-year-old man, had had a chronic winter cough with mucoid sputum for many years, but he had never lost time from his work as a heavy labourer. In April 1961 he noticed the development of ankle swelling; he was admitted to Bethnal Green Hospital and was subsequently transferred to the London Chest Hospital under Dr. J. Smart. He denied having breathlessness prior to the ankle swelling, although he complained of it while he was in hospital. There had been no haemoptysis or chest pain and no evidence of a respiratory infection. For some months he had suffered from morning headaches. He was transferred to Hammersmith Hospital in June 1961.

Examination showed a tall, spare man weighing $59 \mathrm{~kg}$. with long fingers, large facial features and feet, and a high arched palate. There was central cyanosis, worse when he was asleep when he also showed sweating. The hands were warm but there was no clubbing. There was ankle oedema, and the jugular venous pulse was elevated to $3 \mathrm{~cm}$. above the sternal angle and showed a prominent 'a' wave. The blood pressure was $150 / 70 \mathrm{~mm}$. $\mathrm{Hg}$, there was an obvious right ventricular impulse and a pulmonary ejection click and grade 2 systolic murmur with accentuation of the pulmonary component of the second sound. There were wheezes all over the chest but no abnormality in the central nervous system.

Investigations The haemoglobin was $13 \mathrm{~g} . / 100 \mathrm{ml}$., and the packed cell volume was $47 \cdot 5 \%$. The white blood cell and platelet counts were normal as were the venous plasma electrolytes and urea except for a total carbon dioxide content of $39 \mathrm{mM}$. The chest radiograph showed pleural thickening on the right side in the fissures and at the costophrenic angle. There was also gross enlargement of the right side of the heart and of the main pulmonary arteries (Fig. 2). An electrocardiogram showed incomplete right bundle branch block, grade 1 right ventricular hypertrophy, and inversion of the $T$ waves in leads II, III, and aVf. There was a moderately 


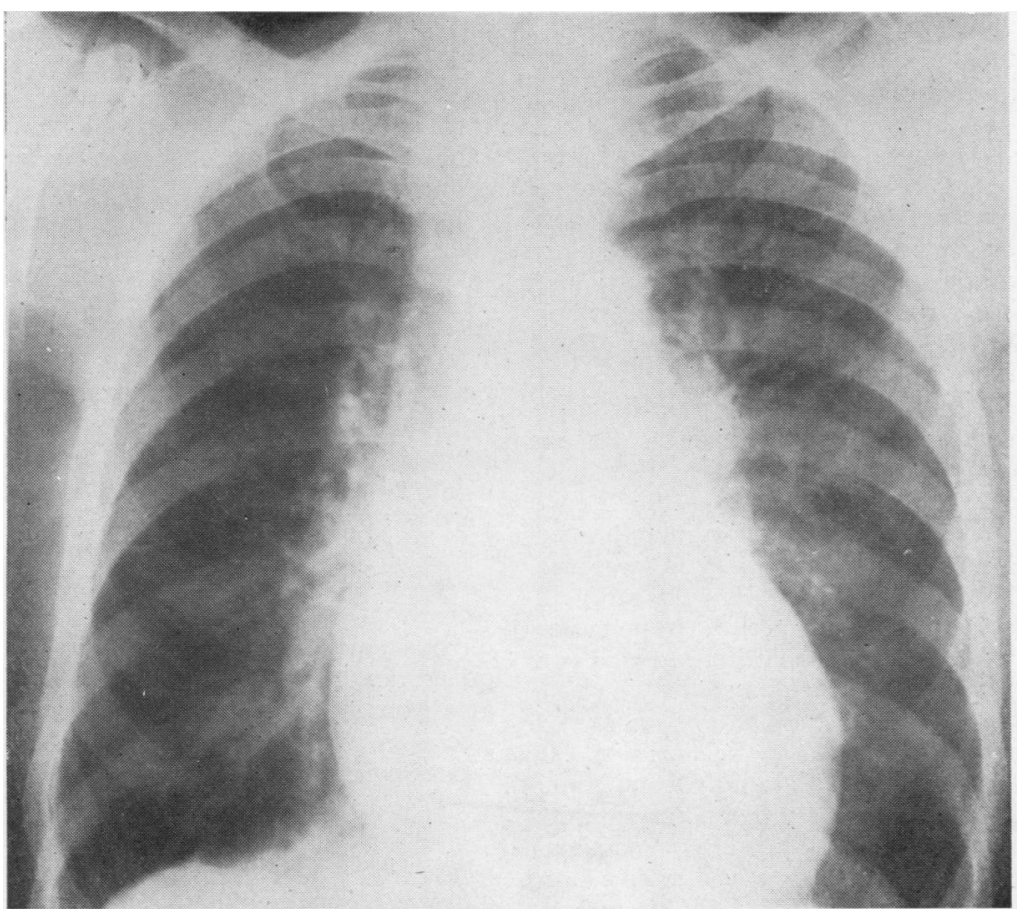

FIG. 2. Case 4. Postero-anterior chest radiograph showing enlarged heart and large main pulmonary arteries with right-sided pleural thickening.

severe generalized abnormality of the electroencephalogram. The mixed venous $\mathrm{PCO}_{2}$ was $78 \mathrm{~mm}$. $\mathrm{Hg}$.

Course The heart failure was treated with salt restriction, digoxin, and chlorothiazide, and a $7 \mathrm{~kg}$. diuresis resulted. The mixed venous $\mathrm{PcO}_{2}$ fell from 78 to $66 \mathrm{~mm}$. $\mathrm{Hg}$. He became considerably more alert (it was evident that he had previously been unduly drowsy despite his denial of this); he was no longer dyspnoeic and had no further headaches.

The clinical features of the four cases are summarized in Table I.

TABLE I

CLINICAL FEATURES

\begin{tabular}{|c|c|c|c|c|c|c|c|c|c|c|c|c|c|c|c|c|c|c|}
\hline \multirow[b]{2}{*}{ Patient } & \multirow[b]{2}{*}{$\begin{array}{c}\text { Age } \\
\\
\overparen{\dot{\rightleftarrows}}\end{array}$} & \multicolumn{2}{|c|}{ Weight } & \multicolumn{5}{|c|}{ History } & \multicolumn{4}{|c|}{ Examination } & \multirow[b]{2}{*}{$\begin{array}{c}\text { Chest } \\
\text { Radiograph }\end{array}$} & \multirow[b]{2}{*}{$\begin{array}{l}\text { Electro- } \\
\text { cardiogram }\end{array}$} & \multirow[b]{2}{*}{$\begin{array}{c}\text { Electro- } \\
\text { encephalogram }\end{array}$} & \multicolumn{3}{|c|}{ Blood } \\
\hline & & $\ddot{0}$ & 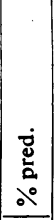 & 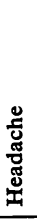 & 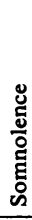 & 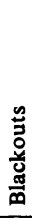 & 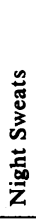 & 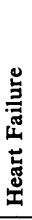 & 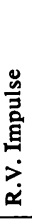 & 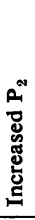 & 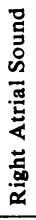 & 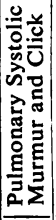 & & & & 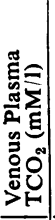 & 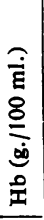 & $\begin{array}{l}\text { فㅇ } \\
\text { ن } \\
\dot{0} \\
\end{array}$ \\
\hline C.P. & 53 & $88 \cdot 5$ & 123 & + & + & + & + & + & + & + & + & + & $\begin{array}{l}\text { Large rt. ven- } \\
\text { tricle; large } \\
\text { main pulm. art., } \\
\text { especially to } \\
\text { right lower lobe }\end{array}$ & $\begin{array}{l}\text { Rt. ventricular } \\
\text { hypertrophy } \\
\text { grade } 3\end{array}$ & $\begin{array}{l}\text { Mild generalized } \\
\text { abnormality }\end{array}$ & 34 & 18 & 67 \\
\hline L.W. & 51 & $80 \cdot 5$ & 108 & + & + & + & + & - & - & - & - & - & $\begin{array}{l}\text { Large rt. ven- } \\
\text { tricle; large } \\
\text { main pulm. art. } \\
\text { Normal }\end{array}$ & $\begin{array}{l}\text { Incomplete } \\
\text { rt. bundle } \\
\text { branch block } \\
\text { Normal }\end{array}$ & Mild generalized & 33 & $\begin{array}{l}17 \\
15\end{array}$ & 51 \\
\hline W.N. & 48 & 59 & 93 & + & + & - & + & + & + & + & - & + & $\begin{array}{l}\text { Large rt. atrium } \\
\text { and ventricle; } \\
\text { large main } \\
\text { pulm. art. }\end{array}$ & $\begin{array}{l}\text { Rt. ventricular } \\
\text { hypertrophy } \\
\text { grade } 1\end{array}$ & $\begin{array}{l}\text { Moderately } \\
\text { severe general- } \\
\text { ized abnorm- } \\
\text { ality }\end{array}$ & 39 & 13 & 47 \\
\hline
\end{tabular}




\section{LUNG FUNCTION TESTS}

METHODS All gas volumes were measured at ambient temperature and pressure (ranging from 18 to $23^{\circ} \mathrm{C}$. and 746 to $770 \mathrm{~mm} . \mathrm{Hg}$ ) with the patients seated at rest unless otherwise stated. No patients had oedema or a raised jugular venous pressure when tested. Predicted weights were obtained from the tables given by Kemsley (1952), and the grading of signs of right ventricular hypertrophy on the electrocardiogram was by the criteria of Goodwin and Abdin (1959).

Ventilatory tests The forced expiratory volume in 1 second (F.E.V.1.0 ) was measured from a tracing obtained on a low resistance spirometer (Bernstein, D'Silva, and Mendel, 1952) with a drum speed of $2 \mathrm{~cm}$./ sec. Normal values used were from an unpublished series. The slow expiratory vital capacity (V.C.) was also measured. Both the F.E.V.1.0 and V.C. were repeated after five minutes' inhalation of a $1 \%$ isoprenaline aerosol in oxygen. The F.E.V ${\cdot{ }_{1 \cdot 0}}$ was expressed also as a percentage of the expiratory V.C. (F.E.V. \% V.C.). Maximal voluntary ventilation (M.V.V.) was measured on the low resistance spirometer by persuading the patient to breathe as deeply and as rapidly as he could for 15 seconds and repeating this on five occasions; the highest value was accepted. The indirect maximal breathing capacity (ind. M.B.C.) was obtained in litres/minute by multiplying the F.E.V..., by 35 ; normal values were those of Needham, Rogan, and McDonald (1954) for M.V.V. The forced inspiratory volume in 1 second (F.I.V.1.0 ) was measured after maximal expiration. Maximal expiratory and inspiratory flow rates (M.E.F.R., M.I.F.R.) were measured as described by Comroe, Forster, DuBois, Briscoe, and Carlsen (1962). The resting ventilation (VE) was measured at the mouth using the respirometer designed by Wright (1955). The subjects had been at rest semirecumbent for at least 20 minutes before this measurement. The normal values used were those of MacLeish (1960).

Total lung capacity and subdivisions These were measured by the closed-circuit helium dilution method (Gilson and Hugh-Jones, 1949). Normal values were predicted from the simplified regression formulae derived by Needham et al. (1954).

Carbon monoxide uptake The whole lung diffusing capacity $\left(\mathrm{D}_{\mathrm{LCO}}\right)$ was measured by the single-breath method of Ogilvie, Forster, Blakemore, and Morton (1957). Normal values were predicted from the regression formula on surface area given by these authors. The results are the mean of at least three and usually five tests on the same day. The 'permeability' (KCO) of Krogh (1915), which is a measure of carbon monoxide uptake per unit of lung volume, was calculated from the same data; the predicted normal figures used were those of McGrath and Thomson (1959).

Distribution of ventilation, blood flow, and ventilationblood flow ratios These were measured by two methods.
The single-breath test devised by West, Fowler, HughJones, and O'Donnell (1957 a, b) was used with the modifications of the original authors described by Read (1959). In this test a mass spectrometer is used as a rapid gas analyser. Results for inequality of ventilation $\left(\frac{\dot{\mathrm{VA}}}{\overline{\mathrm{VA}}}\right)$, inequality of blood flow $\left(\frac{\dot{\mathrm{Q}}}{\overline{\mathrm{VA}}}\right)$, and inequality of ventilation-blood flow ratios $\left(\frac{\dot{\mathrm{V}}}{\dot{\mathrm{QC}}}\right)$ were compressed as rate of change $(\%)$ per $500 \mathrm{ml}$. of expirate.

In addition, at the time of arterial blood sampling the resting ventilation was measured and a three-minute collection of expired gas was made. The $\mathrm{O}_{2}$ and $\mathrm{CO}_{2}$ content of this gas was analysed with the microScholander apparatus. The physiological dead space (VD) was measured by use of the Bohr equation for $\mathrm{CO}_{2}$ :

$$
\mathrm{VD}=\frac{\mathrm{PaCO}_{2}-\mathrm{PECO}_{2}}{\mathrm{PaCO}_{2}} \times \mathrm{VT} \text {, }
$$

where VT=tidal volume in $\mathrm{ml}$., $\mathrm{PaCO}_{2}=$ arterial carbon dioxide tension, and $\mathrm{PECO}_{2}=$ carbon dioxide tension in mixed expired gas, both in $\mathrm{mm}$. $\mathrm{Hg}$. The dead space was also expressed as a ratio of the tidal volume (VD/VT). The alveolar ventilation (VA) in litres/minute (B.T.P.S.) was calculated from the equation

$$
\mathrm{VA}=\frac{\mathrm{VCO}_{2} \times 0.863}{\mathrm{PaCO}_{2}}
$$

where $\mathrm{VCO}_{2}$ is the $\mathrm{CO}_{2}$ output/minute (S.T.P.D.). The difference between the alveolar and the arterial oxygen tensions was also calculated, the alveolar oxygen tension $\left(\mathrm{PAO}_{2}\right)$ being obtained by the alveolar air equation (Riley and Cournand, 1949):

$$
\mathrm{PAO}_{2}=\mathrm{PIO}_{2}-\mathrm{PaCO}_{2}\left(\mathrm{FIO}_{2}+\frac{\left.1-\mathrm{FIO}_{2}\right)}{\mathrm{R}}\right.
$$

where $\mathrm{PIO}_{2}=$ inspired oxygen tension (moist), $\mathrm{FIO}_{2}=$ fractional oxygen concentration in inspired dry gas, and $\mathbf{R}=$ respiratory quotient.

Arterial blood This was sampled from an indwelling needle in the brachial artery while the patients were at rest and semirecumbent. Ventilation was measured at this time at the mouth with a Wright respirometer, and blood samples were collected over a period of one minute after the needle had been in the artery for at least 20 minutes and the ventilation had been at previously obtained resting levels for at least five minutes. The $p \mathbf{H}$ was measured immediately at $38^{\circ} \mathrm{C}$. with an E.I.L. glass electrode and 'Vibron' electrometer. Oxygen content and capacity and carbon dioxide content were measured by the methods of Van Slyke and Neill (1924), and the arterial $\mathrm{PCO}_{2}$ was derived from the nomogram of Singer and Hastings (1948). The arterial oxygen and carbon dioxide tensions $\left(\mathrm{PaO}_{2}\right.$ and $\left.\mathrm{PaCO}_{2}\right)$ were also measured when the patients were breathing room air by the modification of the bubble equilibration technique described by Strang (1961). In this method a mass spectrometer is used for the gas analysis of the bubble.

Mechanics A $15 \mathrm{~cm}$. balloon was passed through the nose into the lower third of the oesophagus, and the changes in oesophageal pressure were measured 

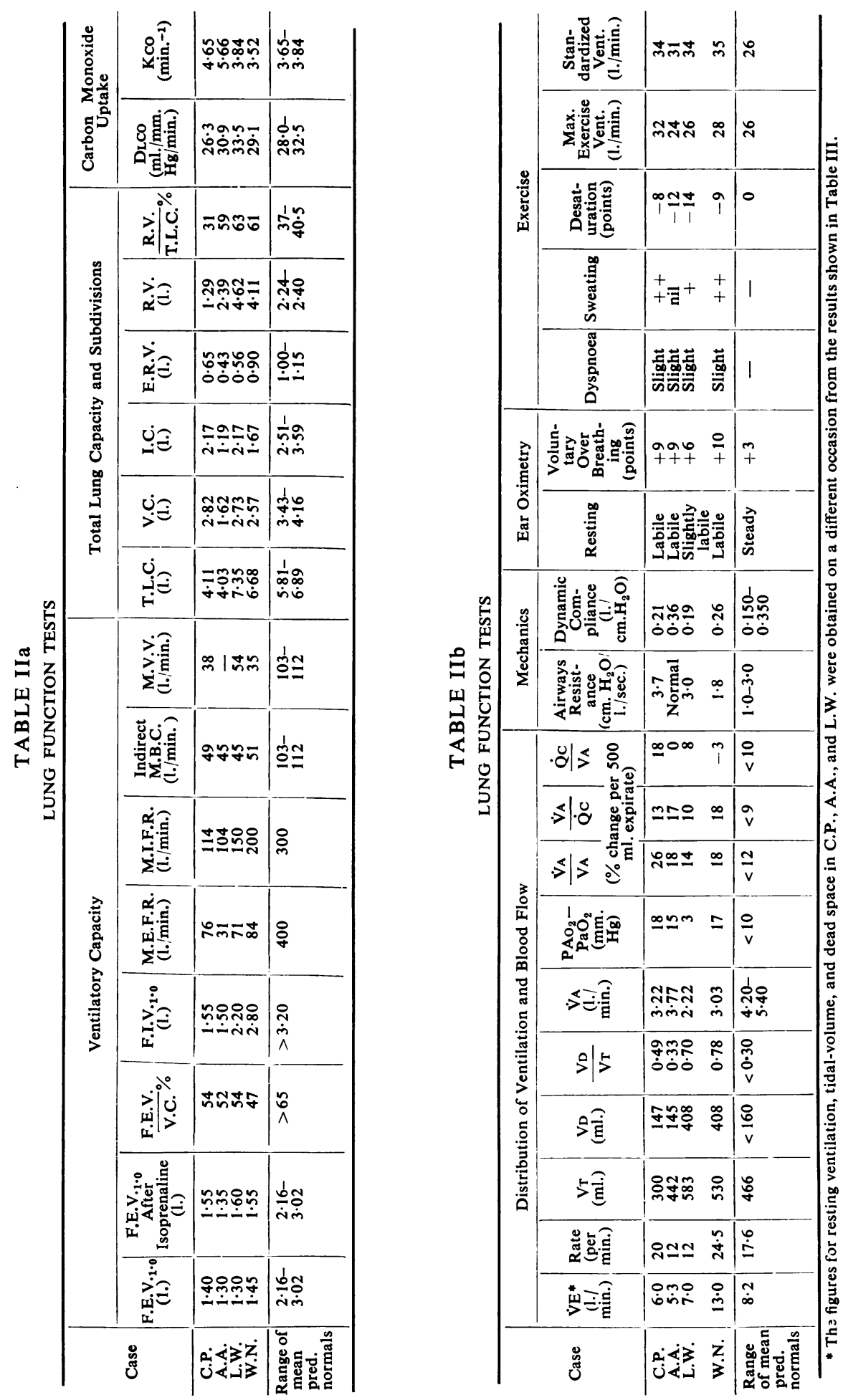

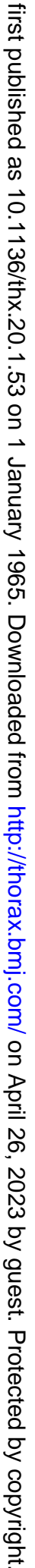


with an electromanometer. Flow was recorded by a Lilly pneumotachometer of negligible resistance, and the volume was obtained by electrical integration of this flow signal. Pressure, flow, and volume were recorded on a Sanborn four-channel recorder. Dynamic compliance and airways resistance were calculated during quiet breathing (Mead and Whittenberger, 1953).

Voluntary overbreathirg This was performed for two minutes and measured by a Wright respirometer; changes in oxygen saturation were followed by ear oximetry and in two cases were confirmed by arterial blood analysis.

Standardized exercise test The step test described by Hugh-Jones and Lambert (1952) was used with a work load of $350 \mathrm{~kg} . \mathrm{M} / \mathrm{min}$. which was sustained for five or six minutes. During the test ventilation was measured at the mouth by the Wright respirometer and changes in arterial oxygen saturation were followed by ear oximetry.

Response to $\mathrm{CO}_{2}$ inhalation The minute ventilation, arterial $\mathrm{PCO}_{2}$, and hydrogen ion activity $\left(\left[\mathrm{H}^{+}\right] \mathrm{a}\right)$ were compared with the subjects breathing $100 \% \mathrm{O}_{2}$ and a $5 \% \mathrm{CO}_{2}, 95 \% \mathrm{O}_{2}$ mixture. Measurements were made after the appropriate gas had been breathed for 20 minutes. The arterial hydrogen ion activity was expressed as moles $\times 10^{-8} /$ litre (or nanoNormal, $\mathrm{nN}$ ) and is the antilog of $(8-p \mathrm{H})$. The measurement of $\mathrm{CO}_{2}$ response was made with the patients breathing high oxygen mixtures so that the effect of an increase in ventilation on oxygen saturation and the consequent ChristiansenDouglas-Haldane effect on the $\mathrm{PaCO}_{2}$ was eliminated. The results are expressed as follows:

(i) $\dot{\mathrm{V}} / \mathrm{PaCO}_{2}$ is the rise in $\dot{\mathrm{V}}$ in $1 . / \mathrm{min}$. divided by the rise in $\mathrm{PaCO}_{2}$ in $\mathrm{mm}$. $\mathrm{Hg}$

(ii) $\dot{V} E /\left[H^{+}\right]$a similarly is the rise in $\dot{V}_{E}$ in $1 . / m i n$. per $1 . \times 10^{-9} \mathrm{~mol} / 1$. in $\left[\mathrm{H}^{+}\right] \mathrm{a}$

(iii) $\dot{\mathrm{V}}_{\mathrm{ER}} / \mathrm{PaCO}_{2} \cdot \dot{\mathrm{V}}_{\mathrm{ER}}=\frac{\mathrm{VE} \text { on } 5 \% \mathrm{CO}_{2}, 95 \% \mathrm{O}_{2}}{\mathrm{VE} \text { on } 100 \% \mathrm{O}_{2}}$

This proportionate rise in $\mathrm{VE}$ over resting levels is expressed per $1 \mathrm{~mm}$. $\mathrm{Hg}$ rise in $\mathrm{PaCO}_{2}$. (iv) $\dot{\operatorname{VER}} /\left[\mathrm{H}^{+}\right] \mathrm{a}$ is similarly the proportionate rise of VE over resting values per $1 \times 10^{-8} \mathrm{~mol} / \mathrm{l}$. rise in $\left[\mathrm{H}^{+}\right]$a.

These methods are a combination of those of Alexander, West, Wood, and Richards (1955) and of Garlind and Linderholm (1958).

Mixed venous $\mathrm{PCO}_{2}$ This was measured by the rebreathing method as described by Campbell and Howell (1960). In most cases the $\mathrm{CO}_{2}$ content of the bag was measured with a simplified Haldane apparatus (Campbell, 1960) but in some cases the $\mathrm{CO}_{2}$ tension during the second stage of the procedure was followed on the mass spectrometer.

RESULTS (see Tables II and III) Predicted normal values in some cases vary for each patient but as this variation is not great, the range of predicted values for the four patients is given.

Ventilatory tests The F.E.V $\cdot_{1 \cdot 0}$ was reduced to about $50 \%$ of the predicted in all cases with a reduced F.E.V. \% V.C., indicating airways obstruction. The M.I.F.R. was less reduced than the M.E.F.R.

In two of the three patients who performed the test the maximal voluntary ventilation (M.V.V.) was less than the indirect maximal breathing capacity.

Resting ventilation is labile in these patients and tends to increase when efforts are made to measure it, but in thiee patients figures below normal were obtained. In the fourth (W.N.) the ventilation was 13.0 1./minute. We were reluctant to accept this as a true resting level but after 20 minutes breathing at this minute volume the arterial $\mathrm{PCO}_{2}$ was $65 \mathrm{~mm}$. $\mathrm{Hg}$. A similar figure for ventilation was obtained on three further occasions. Despite the variation in minute volume none of the patients showed a gross irregularity of rhythm or depth of breathing.

TABLE III

MINUTE VENTILATION AND ARTERIAL BLOOD BREATHING AIR, 100\% OXYGEN AND A MIXTURE OF $5 \%$ CARBON DIOXIDE AND $95 \%$ OXYGEN

\begin{tabular}{|c|c|c|c|c|c|c|c|c|c|c|c|c|c|c|c|c|c|c|}
\hline \multirow{3}{*}{\multicolumn{3}{|c|}{ Inspired gas }} & \multirow{2}{*}{\multicolumn{3}{|c|}{$\begin{array}{c}\text { Minute Ventilation } \\
\text { (1./min.) }\end{array}$}} & \multicolumn{9}{|c|}{ Arterial Blood } & \multicolumn{4}{|c|}{ Response to $\mathrm{CO}_{2}$ Inhalation } \\
\hline & & & & & & \multicolumn{3}{|c|}{$p \mathbf{H}$} & \multicolumn{2}{|c|}{$\mathrm{SaO}_{2}(\%)$} & \multirow{2}{*}{$\begin{array}{c}\begin{array}{c}\mathrm{PaO}_{2} \\
\mathrm{(mm}\end{array} \\
\mathbf{H g})\end{array}$} & \multicolumn{3}{|c|}{$\mathrm{PaCO}_{2}(\mathrm{~mm} . \mathrm{Hg})$} & \multirow{2}{*}{$\frac{\dot{\mathrm{VE}}}{\mathrm{PaCO}_{2}}$} & \multirow{2}{*}{$\frac{\dot{V} E}{\left[H^{+}\right] \mathrm{a}}$} & \multirow{2}{*}{$\frac{\text { VER }}{\mathrm{PaCO}_{2}}$} & \multirow{2}{*}{$\frac{\dot{V}_{\text {ER }}}{\left[\mathrm{H}^{+}\right] \mathrm{a}}$} \\
\hline & & & \multirow{2}{*}{$\begin{array}{r}\text { Air } \\
3 \cdot 8 \\
4 \cdot 4 \\
5 \cdot 9 \\
13 \cdot 0\end{array}$} & \multirow{2}{*}{$\begin{array}{c}100 \% \\
\mathrm{O}_{2}\end{array}$} & \multirow{2}{*}{$\mid$\begin{tabular}{c|}
$5 \% \mathrm{CO}_{2}$ \\
$95 \% \mathrm{O}_{2}$ \\
$16 \cdot 5$ \\
12.7 \\
21.0 \\
16.0
\end{tabular}} & \multirow{2}{*}{\begin{tabular}{l|} 
Air \\
$7 \cdot 31$ \\
$7 \cdot 31$ \\
$7 \cdot 32$ \\
$7 \cdot 32$
\end{tabular}} & \multirow{2}{*}{$\begin{array}{c}100 \% \\
\mathrm{O}_{2} \\
7 \cdot 29 \\
7 \cdot 29 \\
7 \cdot 31 \\
7 \cdot 30\end{array}$} & \multirow{2}{*}{\begin{tabular}{|c|}
$5 \% \mathrm{CO}_{2}$ \\
$95 \% \mathrm{O}_{2}$ \\
$7 \cdot 13$ \\
$7 \cdot 22$ \\
$7 \cdot 24$ \\
$7 \cdot 25$ \\
\end{tabular}} & \multirow{2}{*}{\begin{tabular}{r|} 
Air \\
77 \\
90 \\
89 \\
81
\end{tabular}} & \multirow{2}{*}{\begin{tabular}{|c|}
$100 \%$ \\
$\mathrm{O}_{2}$ \\
105 \\
108 \\
109 \\
105 \\
\end{tabular}} & & \multirow{2}{*}{$\begin{array}{l}\text { Air } \\
83 \\
58 \\
55 \\
65\end{array}$} & \multirow{2}{*}{$\begin{array}{c}100 \% \\
\mathrm{O}_{2}\end{array}$} & \multirow{2}{*}{\begin{tabular}{|c|}
$5 \% \mathrm{CO}_{2}$ \\
$95 \% \mathrm{O}_{2}$ \\
123 \\
70 \\
66 \\
83
\end{tabular}} & & & & \\
\hline $\begin{array}{l}\text { C.P. } \\
\text { A.A. } \\
\text { L.W. } \\
\text { W.N. }\end{array}$ & $\begin{array}{l}. \\
\because \\
\because \\
\end{array}$ & $\begin{array}{l}. \\
\therefore \\
.\end{array}$ & & & & & & & & & $\begin{array}{l}52 \\
67 \\
66 \\
55\end{array}$ & & & & $\begin{array}{l}0.52 \\
0.98 \\
1.27 \\
0.54\end{array}$ & $\begin{array}{l}0.53 \\
0.98 \\
1.47 \\
1.07\end{array}$ & $\begin{array}{l}0 \cdot 13 \\
0 \cdot 18 \\
0 \cdot 15 \\
0.06\end{array}$ & $\begin{array}{l}0.13 \\
0.18 \\
0.18 \\
0.11\end{array}$ \\
\hline Normal & $\ldots$ & . & $8 \cdot 2$ & $\overline{8 \cdot 8}$ & $16 \cdot 3$ & $7 \cdot 39$ & $7 \cdot 39$ & $7 \cdot 37$ & $>95$ & $>105$ & 95 & 42 & 42 & 45 & $2 \cdot 50$ & $4 \cdot 54$ & $0 \cdot 28$ & 0.51 \\
\hline
\end{tabular}

* See text for explanation of these symbols. 
Total lung capacity and subdivisions The total lung capacity (T.L.C.) was normal in two patients and reduced in the two overweight patients. The inspiratory capacity (I.C.) was reduced in all patients, as was the expiratory reserve volume (E.R.V.). The two patients with a normal T.L.C. had an increased residual volume (R.V.); a third patient had a raised R.V./T.L.C.\% but in his case this was due to the combination of a normal R.V. and a reduced T.L.C.

Carbon monoxide uptake This was not reduced whether expressed as carbon monoxide uptake for the whole lung (DLCO) or as uptake per unit of lung volume (KCO).

Distribution of ventilation, blood flow, and ventilationblood flow ratios The single-breath test showed inequality of ventilation in all patients. In one patient (L.W.) there was no abnormality of the ventilation-blood flow ratios, and the alveolararterial oxygen tension difference was not increased, but the other three patients all showed some imbalance between ventilation and blood flow which contributed to the arterial oxygen desaturation. Alveolar ventilation was below normal in all, and two patients had considerably increased physiological dead space.

Arterial blood Resting samples showed arterial oxygen desaturation, elevation of $\mathrm{PCO}_{2}$, and a reduced $p \mathrm{H}$ in all four patients. In three there was an increased alveolar-arterial $\mathrm{Po}_{2}$ difference, and the desaturation was greater than could be explained by underventilation alone. On breathing $100 \%$ oxygen, the arterial oxygen saturation in all patients rose to at least $105 \%$ excluding a significant right to left shunt.

Mechanics The dynamic compliance was normal in all patients. Airways resistance was increased in one patient (C.P.) and at the upper limit of normal in another (L.W.).
Voluntary overbreathing Oximeter readings at rest in these patients were very labile. Introducing a mouth-piece usually resulted in a rise in ventilation giving an increase in oximeter reading of several per cent which persisted for five or more minutes. A two-minute period of voluntary over-ventilation increased the saturation in all cases.

Standardized exercise test All four patients were able to complete five minutes of the relatively severe test without severe dyspnoea. In two patients there was profuse sweating. They showed a rapid desaturation in the first minute of exercise after which no further fall in oximeter reading occurred. Though the patients achieved a steady level of ventilation in the fourth and fifth minutes of exercise, which was considerably below their maximum breathing capacity (either M.V.V. or indirect M.B.C.), they all went into ventilatory debt. The standardized ventilation (which gives a measure of the overall ventilatory cost per minute of a given piece of exercise) was only slightly above normal in these four patients. In one patient (L.W.) the end-expiratory $\mathrm{PO}_{2}$ and $\mathrm{PCO}_{2}$ were measured at the mouth using a mass spectrometer while mild exercise was carried out on a bicycle. The oximeter reading fell $15 \%$ during this exercise and the endexpiratory $\mathrm{Po}_{2}$ fell from $102 \mathrm{~mm} . \mathrm{Hg}$ to $50 \mathrm{~mm}$. $\mathrm{Hg}$ while the end-expiratory $\mathrm{PCO}_{2}$ rose from $42 \mathrm{~mm}$. $\mathrm{Hg}$ to $61 \mathrm{~mm}$. $\mathrm{Hg}$. These changes, combined with the poor ventilatory response, suggest that the desaturation on exercise was due to a worsening of the underventilation. These changes on exercise occurred at a time when the patient (L.W.) was maintaining a mixed venous $\mathrm{PCO}_{2}$ of $53 \mathrm{~mm}$. $\mathrm{Hg}$ and was symptomfree.

Response to $\mathrm{CO}_{2}$ inhalation (Table III and Figs 3 and 4). For comparison we have assumed that the relationships between $\mathrm{PaCO}_{2}$ or $\left[\mathrm{H}^{+}\right]$a and ventilation are linear. Figure 3 shows the rise in $\mathrm{PaCO}_{2}$ or $\left[\mathrm{H}^{+}\right]$a required to double the resting ventilation, i.e., $\dot{\mathrm{V}}_{\mathrm{E}} \mathrm{R}=2 \cdot 0$. By all methods of assessment the

TABLE IV

SUMMARY OF ABNORMALITIES OF LUNG FUNCTION APART FROM THE CHANGES FOLLOWING ALVEOLAR UNDERVENTILATION

\begin{tabular}{|c|c|c|c|c|c|c|c|}
\hline Patient & $\begin{array}{l}\text { Ventilatory } \\
\text { Capacity }\end{array}$ & $\begin{array}{l}\text { Lung } \\
\text { Volumes }\end{array}$ & $\begin{array}{l}\text { Physiological } \\
\text { Dead Space }\end{array}$ & $\begin{array}{c}\text { Inequality of } \\
\text { Ventilation }\end{array}$ & $\begin{array}{l}\text { Inequality of } \\
\text { Ventilation- } \\
\text { blood Flow } \\
\text { Ratios }\end{array}$ & $\begin{array}{l}\text { Alveolar-arterial } \\
\mathrm{Po}_{2} \text { Difference }\end{array}$ & $\begin{array}{c}\text { Airways } \\
\text { Resistance }\end{array}$ \\
\hline $\begin{array}{l}\text { C.P. } \\
\text { A.A. } \\
\text { L.W. } \\
\text { W.N. }\end{array}$ & $\begin{array}{c}40-50 \% \\
\text { of } \\
\text { predicted }\end{array}$ & $\begin{array}{l}\text { Small T.L.C.; } \\
\text { small R.V. } \\
\text { Small T.L.C. } \\
\text { Large R.V. } \\
\text { Large R.V. }\end{array}$ & $\begin{array}{l}\text { Normal } \\
\text { Normal } \\
\text { Large increase } \\
\text { Large increase }\end{array}$ & $\begin{array}{l}\text { Moderate } \\
\text { Moderate } \\
\text { Slight } \\
\text { Moderate }\end{array}$ & $\begin{array}{l}\text { Moderate } \\
\text { Moderate } \\
\text { Slight } \\
\text { Moderate }\end{array}$ & $\begin{array}{l}\text { Increased } \\
\text { Increased } \\
\text { Normal } \\
\text { Increased }\end{array}$ & $\begin{array}{l}\text { Increased } \\
\text { Normal } \\
\text { Normal } \\
\text { Normal }\end{array}$ \\
\hline
\end{tabular}



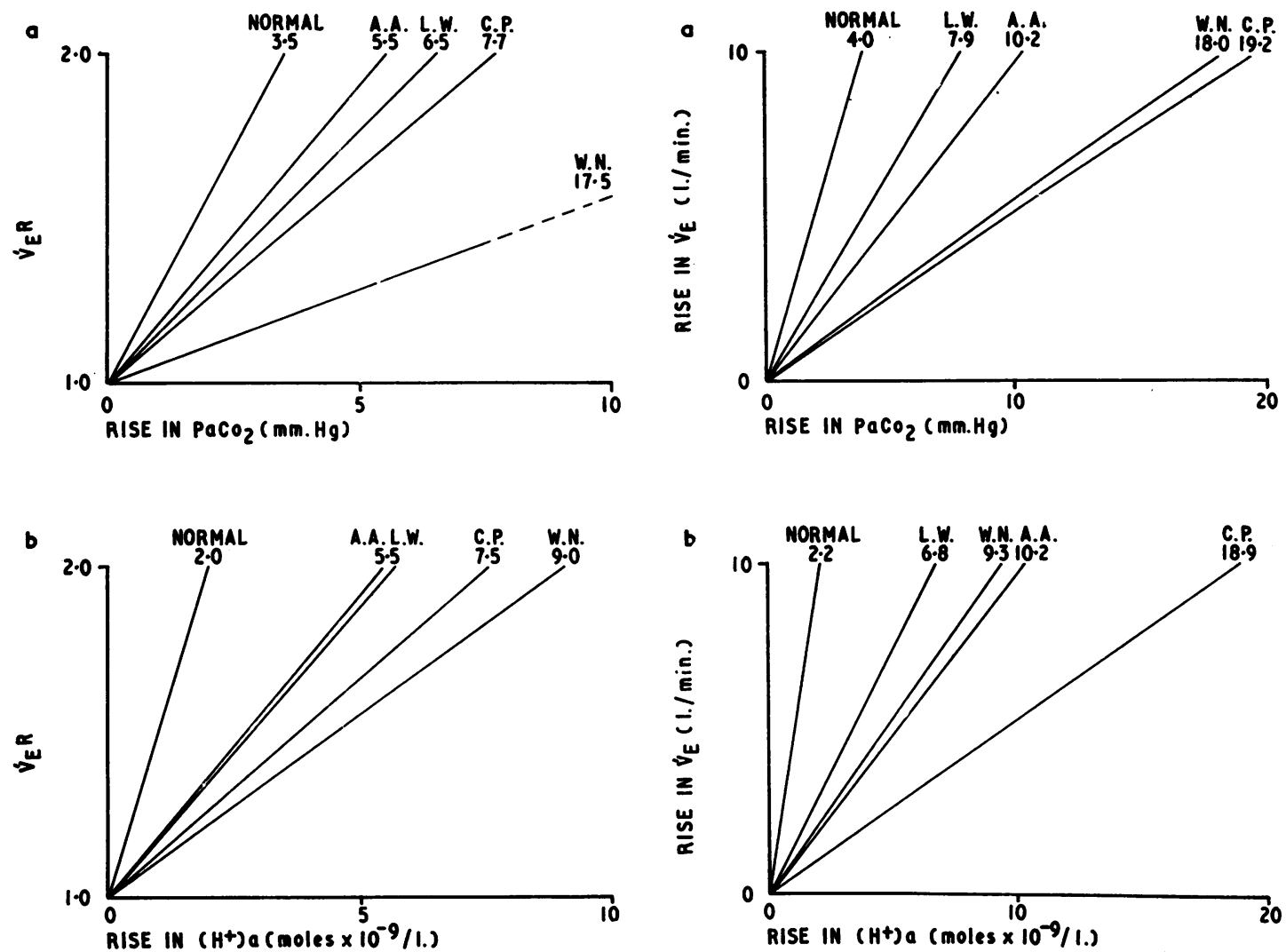

FIG. 3. (a) Rise in arterial $\mathrm{PCO}_{2}\left(\mathrm{PaCO}_{2}\right)$ required to double the resting ventilation $\left(\dot{V}_{E} R=2\right) ;(b)$ rise in arterial hydrogen ion activity $\left(\left[\mathrm{H}^{+}\right] a\right)$ required to double the resting ventilation $\left(\dot{V}_{n} R=2\right)$.

response to carbon dioxide inhalation can be seen to be impaired.

A summary of the abnormalities of lung function in these patients, other than the changes following underventilation, is given in Table IV.

\section{DISCUSSION}

The main abnormality in these four patients was inadequate alveolar ventilation at rest; this was associated with a poor ventilatory response to the inhalation of carbon dioxide and to the stress of exercise. These changes were out of proportion to those that we would expect in patients with airways obstruction of a corresponding degree. The headaches, somnolence, tremor, polycythaemia, and right heart failure which occurred in our patients were probably accounted for by the alveolar underventilation; they frequently accompany the under-

FIG. 4. (a) Rise in arterial $\mathrm{PcO}_{2}\left(\mathrm{PacO}_{2}\right)$ required to raise the resting ventilation $\left(\dot{V}_{\mathrm{E}}\right)$ by 10 litres per minute; $(b)$ rise in arterial hydrogen ion activity $\left(\left[\mathrm{H}^{+}\right] a\right)$ required to raise the resting ventilation by 10 litres per minute.

ventilation which occurs in the chronic bronchitic with severe airways obstruction, but in our patients they were much more prominent than the symptoms produced by the airways obstruction which was not severe. It also seems likely that worsening of the underventilation with increased acidity of the arterial blood led to the profuse sweating observed when the patients were asleep, exercising or breathing carbon dioxide mixtures.

Although the finding of underventilation satisfactorily explains many of the clinical features, we do not know why it occurred. Chronic bronchitis with airways obstruction probably accounted for the reduced F.E.V ${ }_{1.0}$ and F.E.V. \% V.C. and the inequalities of ventilation and blood flow that we found in all our patients, for the increase in residual volume in L.W. and W.N., and for the increase in airways resistance in C.P. However, we do not think that the reduction in F.E.V. accounted for the 


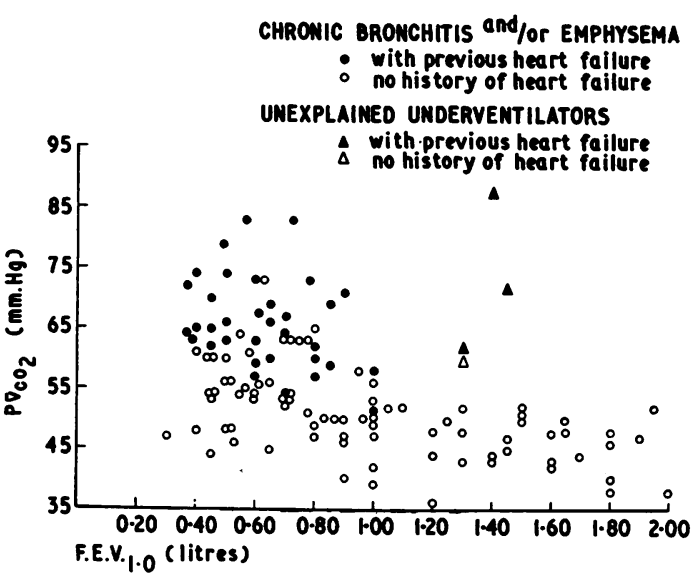

FIG. 5. The F.E. $V_{\cdot_{1} \cdot 0}$ plotted against the mixed venous $\mathrm{PCO}_{2}\left(\mathrm{PV}_{\mathrm{CO}_{2}}\right)$ in 113 cases of irreversible airways obstruction due to chronic bronchitis and/or emphysema and in four patients with unexplained underventilation. All measurements were made when the patients were in their 'chronic' state.

alveolar underventilation because we have not seen it occur in chronic bronchitis unless the F.E.V.1.o is 1 litre or less (see Fig. 5), whereas our four patients had an F.E.V..1.0 of 1.3 litres or more. There were other points of distinction between these four patients and the majority of men with chronic bronchitis and airways obstruction. These may be considered under six headings:

DYSPNOEA Gur patients, except when in heart failure, only admitted to very slight dyspnoea. For instance, A.A. claimed no difficulty in climbing 100 stairs to his work as a bricklayer, and L.W.'s breath-holding time was abnormally long.

EXERCISE TOLERANCE We have found very few patients with chronic bronchitis, airways obstruction, and an arterial $\mathrm{PCO}_{2}$ over $60 \mathrm{~mm}$. $\mathrm{Hg}$ who have been able to complete the exercise test we used, but these four men did so without difficulty. During this test men with chronic bronchitis usually achieve a maximum exercise ventilation at least as great as their indirect maximal breathing capacity, show an increased standardized ventilation and only slight desaturation. Our patients, while going into ventilatory debt, had a maximum exercise ventilation below their maximum breathing capacity; the standardized ventilation was only slightly elevated, yet severe desaturation occurred.

RESTING VENTILATION Three of our patients had a reduced resting ventilation which is not often found in chronic bronchitis or emphysema. In two of the men there was virtual apnoea at night; when awake there was great minute-to-minute variation in ventilation.

VOLUNTARY OVERBREATHING Two minutes of overbreathing in our patients raised their oxygen saturation by at least $6 \%$ (as measured with an ear oximeter), whereas in chronic bronchitis the average rise is less than $3 \%$ (Wilson, Borden, Ebert, Wells, and Johnson, 1950).

COMA Although coma associated with carbon dioxide retention is seen in chronic bronchitis with airways obstruction, it usually occurs in exacerbations of infection or after the use of cxygen or sedatives. Both C.P. and L.W., however, had episodes of apnoea and coma without an obvious precipitating cause.

RIGHT HEART FAILURE The appearance of heart failure as the presenting feature in three of our patients contrasts with its more usual appearance as a late complication of severe chronic bronchitis. This syndrome could be confused with the underventilation of 'chronic bronchitis and emphysema'. Because of this we have discussed at some length these points of distinction, which are summarized in Table V.

TABLE V

SUMMARY OF FEATURES DISTINGUISHING CHRONIC BRONCHITIS FROM UNEXPLAINED UNDERVENTII ATION

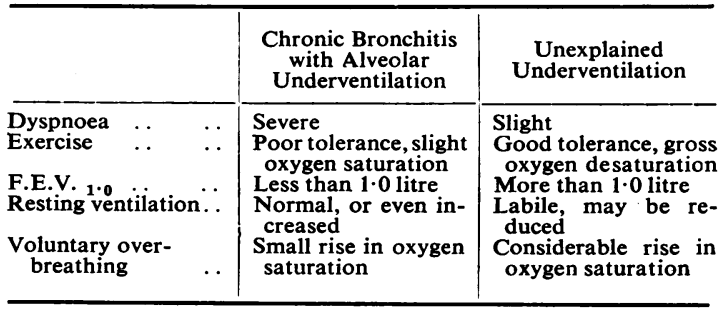

We do not think that the underventilation in our patients could be accounted for by obesity or a defined neurological disease. Two of the patients (C.P. and A.A.) were overweight and had the small lung volumes often found in the obese, but their obesity was much less marked than in any of the reported cases, and they both failed to lower their $\mathrm{PCO}_{2}$ on losing 9 and $17 \mathrm{~kg}$. respectively. None of the four patients had a history of encephalitis; they had diffusely abnormal electroencephalograms (attributed to hypoxia and carbon dioxide retention) but the only local neurological abnormalities found 
in our patients during many examinations were transitory nystagmus in C.P. and transitory diplopia in L.W. Both these patients had periods of complete apnoea, and it seems possible that these abnormalities were the result of hypoxia rather than related to the cause of the underventilation. Primary polycythaemia vera with a midbrain vascular lesion resulting in underventilation was considered as a possibility in C.P., but there has been no splenomegaly and no increase in the white blood cells or platelets.

Two patients (L.W. and W.N.) had very large physiological dead spaces. In W.N. the increase in dead space was such that an increased minute volume provided inadequate alveolar ventilation; the other features in this patient were identical with those of the rest of the group. In three previously reported cases (Ratto et al., 1955; Richter et al., 1957; and case 2 of Rodman et al., 1962) there has been an increase in physiological dead space to between 220 and $280 \mathrm{ml}$. An increase of the physiological dead space is common in chronic bronchitis and emphysema but may also be found in pulmonary embolism. Thromboembolism can be an unsuspected cause of chronic right heart failure (Owen, Thomas, Castleman, and Bland, 1953), but in reported cases dyspnoea has been severe and carbon dioxide retention absent (Ehrner, Garlind, and Linderholm, 1959), so it seems unlikely to have been the cause in our patients. Nevertheless at necropsy in the case described by Lawrence (1959) there were numerous pulmonary infarcts; these were thought to be recent and to be a complication of polycythaemia.

The marked underventilation in our patients therefore remains unexplained; their clinical and physiological features resemble those of the 10 patients previously described, all but one of whom (a 36-year-old woman reported from the Massachusetts General Hospital in 1956) have been men between the ages of 30 and 60 years. The aetiology of the syndrome is probably diverse; chronic bronchitis may have played a part in its production in our patients similar to that played by obesity in other cases. But there must be another as yet unrecognized defect, and this probably lies in the central nervous system. Some neurological or psychiatric abnormality has been observed in eight of the 10 previously reported cases; three were of low intelligence, one had a positive Wassermann reaction in the cerebrospinal fluid, one was schizophrenic and had been treated with frequent insulin comas, one had persistent hiccough, one was 'depressed and obsessive', and in the probable case of Naeye (1961) focal loss of medullary cells with reactive gliosis was found post mortem. Of our patients, apart from the diplopia in L.W., another $\underset{\vec{\rho}}{\vec{\rho}}$ (W.N.) was well below average in intelligence.

It is interesting to speculate on the role of under- $\bar{\sigma}$ ventilation in the aetiology of cor pulmonale in $\frac{\bar{c}}{\frac{5}{\sigma}}$ patients with airways obstruction. In emphysema $\stackrel{\mathbb{\Omega}}{\Omega}$ the disturbance of alveolar and blood gases co- \# exists with anatomical loss of the pulmonary vascular bed, and the respective importance of each of these factors is not clear. Nevertheless alveolar underventilation appears to be the most consistent $\stackrel{\sigma}{\sigma}$ clinical association (Rossier and Bühlmann, 1954; $\vec{x}$ Ferrer and Harvey, 1959; Campbell and Short, i 1960), though there is doubt whether the changes in the alveolar gases or in the blood gases are the $\vec{c}$ more important (Fishman, 1961). Our cases with $\omega$

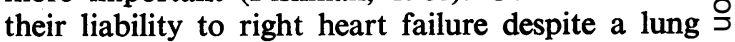
function which is not greatly disturbed are like those occurring in obesity in having underventilation as the only obvious factor. They confirm our general experience that cor pulmonale in patients with $₹$ irreversible airways obstruction is more common $\vec{\theta}$ at any given level of F.E.V. $.1 .0_{0}$ in those patients who of have elevation of the $\mathrm{PCO}_{2}$ (see Fig. 5).

Our experience does not allow us to assess the prognosis of this syndrome. Heart failure has responded to rest, digoxin, and diuretics, but $\bar{\partial}$ attempts to produce a long-lasting increase in ventila- $\stackrel{\circ}{\circ}$ tion have been unsuccessful except for an apparently $\varrho$ good response to dichlorphenamide in A.A. and a $\overrightarrow{\vec{O}}$ partial response to oral amiphenazole in L.W. The alarming apnoeic episodes are an obvious risk to life, but C.P. and A.A. are still at work five years after the first appearance of right heart failure, and when free from oedema they are only slightly disabled. Successful treatment would produce ade- $x$ quate ventilatory stimulation without side effects and would presumably greatly improve the prognosis. It is however not available.

\section{SUMMARY}

Four cases of unexplained underventilation are described. Clinically they were characterized by $N$ headache, somnolence, sudden episodes of unconsciousness, and a tendency to right heart failure. 0 There was little dyspnoea. The dominant defect in $\omega$ lung function was alveolar underventilation, associated in three of the patients with low overall ventila- $O$ tion. In addition there were clinical and physio- $\mathbb{\Phi}$ logical features suggesting that all these patients had. mild chronic bronchitis, but reasons are given tor considering that this did not account for the underventilation.

The aetiology is unknown. Attempts to stimulate ventilation have been largely unsuccessful. 
All these patients were originally seen at other hospitals, and we are most grateful to Dr. M. O. J. Gibson, Dr. V. Wynne, Dr. R. Asher, and Dr. J. Smart for permission to quote their findings in these cases. We should also liks to thank Dr. C. M. Fletcher and Dr. P. Hugh-Jones, under whose care these patients were at this hospital, for their criticism and advice, and Miss E. Buchanan for help with the lung function tests.

\section{REFERENCES}

Alexander, J. K. West, J. R., Wood, J. A, and Richards, D. W. (1955). Analysis of the respiratory response to carbon dioxide inhalation in varying clinical states of hypercapnia, anoxia, inhalation in varying clinical states of hypercapnia,
and acid-base derangement. J. clin. Invest. 34,511 .

Bernstein, L., D'Silva, J. L., and Mendei, D. (1952). The effect of the rate of breathing on the maximum breathing capacity determined with a new spirnmeter. Thorax, 7,255 .

Campbell, E. J. M. (1960). Simplification of Haldane's apparatus for measuring $\mathrm{CO}_{2}$ concentration in respired gases in clinical practice. Brit. med. J., $1,457$.

- and Howell, J. B. L. (1960). Simple rapid methods of estimating arterial and mixed venous $\mathrm{pCO}_{2}$. Ibid., 1, 458.

and Short, D.S. (1960). The cause of oedema in "cor pulmonale". Lancet, 1, 1184 .

Cherniack, R. M., and Snidal, D. P. (1956). The effect of obstruction to breathing on the ventilatory response to $\mathrm{CO}_{2}$.J. clin. Invest., 35,1286 .

Comroe, J. H., jr., Forster, R. E., DuBois, A. B., Briscoe, W. A., and Carlsen, E. (1962). The Lung, p. 197. Year Book Medical Publishers, Chicago.

Efron, R., and Kent, D. C. (1957). Chronic respiratory acidosis due to brain disease. Arch. Neurol. Psychiat. (Chic.), 77, 575

Ehrner, L., Garlind, T., and Linderholm, H. (1959). Chronic cor pulmonale following thromboembolism. Acta med. scand., 164, 279.

Ferrer, M. I., and Harvey, R. M. (1959). In Pulmonary Circulation. An International Symposium, 1958, p. 184, ed. W. R. Adams and An International Symposium, $1958, \mathrm{p} .184$,
I. Vieth. Grune and Stratton, New York.

Fishman, A. P. (1961). Respiratory gases in the regulation of the pulmonary circulation. Physiol. Rev., 41, 214.

Garlind, T., and Linderholm, H. (1958). Hypoventilation syndrome in a case of chronic epidemic encephalitis. Acta med. scand., $162,333$.

Gilbert, R., Sipple, J. H., and Auchincloss, J. H. jr. (1961). Respiratory control and work of breathing in obese subjects. J. appl. tory control and
Physiol., 16, 21.

Gilson, J. C., and Hugh-Jones, P. (1949). The measurement of the total lung volume and breathing capacity. Clin. Sci., 7. 185.

Goodwin, J.F., and Abdin, Z.H.(1959). The cardiogram of congenital and acquired right ventricular hypertrophy. Brit. Heart J., $21,523$.

Hadorn, W., and Scherrer, M. (1959). Essentielle alveoläre Hypoventilation mit Cor pulmonale. Schweiz. med. Wschr., 89, 647 .

Hugh-Jones, P., and Lambert, A. V. (1952). A simple standard exercise test and its use for measuring exertion dyspnoea. Brit. med. $J ., 1,65$.

Kemsley, W. F. F. (1952). Body weight at different ages and heights. Ann. Eugen. (Lond.), 16, 316.

Krogh, M. (1915). The diffusion of gases through the lungs of man. J. Physiol. (Lond.), 49, 271.

Lawrence, L. T. (1959). Idiopathic hypoventilation, polycythemia and cor pulmonale. Amer. Rev. resp. Dis. 80,575 .

McGrath, M. W., and Thomson, M. L. (1959). The effect of age, body size and lung volume change on the alveolar-capillary permea-
bility and diffusing capacity in man. J. Physiol. (Lond.), 146, 572.
MacLeish, M. H. (1960). M.Sc. Thesis, London University.

Massachusetts General Hospital (1956). Medical Grand Rounds, ed. L. H. Smith. Case 347, hypoventilation syndrcme. Amer. Practit., 7, 1165.

Mead, J., and Whittenberger, J. L. (1953). Physical properties of human lungs measured during spontaneous respiration. J. appl. Physiol., 5, 779.

Naeye, R. L. (1961). Alveolar hypoventilation and cor pulmonale secondary to damage to the respiratory center. Amer. J. Cardiol., $8,416$.

Needham, C. D., Rogan, M. C., and McDonald, I. (1954). Normal standards for lung volumes, intrapulmonary gas-mixing, and maximum breathing capacity. Thorax, 9, 313 .

Newman, W., Feltman, J. A., and Devlin, B. (1951). Pulmonary function studies in polycythemia vera. Amer. J. Med., 11, 706.

Ogilvie, C. M., Forster, R. E., Blakemore, W. S., and Morton, J. W. (1957). A standardized breath holding technique for the clinical measurement of the diffusing capacity of the lung for carbon monoxide. J. clin. Invest., 36, 1.

Owen, W. R., Thomas, W. A.,Castleman, B., and Bland, E. F. (1953) Unrecognized emboli to the lungs with subsequent cor pulmonale. New Engl. J. Med., 249, 919.

Pare, P., and Lowenstein, L. (1956). Polycythemia associated with disturbed function of the respiratory centre. Blood, 11, 1077 .

Prime, F. J., and Westlake, E. K. (1954). The respiratory response to $\mathrm{CO}_{2}$ in emphysema. Clin. Sci., 13, 321 .

Ratto, O., Briscoe, W. A. Morton, J. W., and Comroe, J. H. jr. (1955). Anoxemia secondary to polycythemia and polycythemia secondary to anoxemia. Amer. J. Med., 19, 958.

Read, J. (1959). Pulmonary ventilation and perfusion in normal subjects and in patients with emphysema. Clin. $S(i ., 18,465$.

Richards, D. W., Fritts, H. W. Jr., and Davis, A. L. (1958). Observations on the control of respiration in $\mathrm{cmphysema:} \mathrm{the} \mathrm{effects}$ of oxygen on ventilatory response to $\mathrm{CO}_{2}$ inhalation. Trans. Ass. Amer. Phycns, 71, 142.

Richter, T. West, J. R. and Fishman, A.P. (1957). The syndrcme of alveolar hypoventilation and diminished sensitivity of the alveolar hypoventilation and diminished sensit.

Riley, R. L., and Cournand, A. (1949). "Ideal" aiveolar air and the analysis of ventilation-perfusion relationships in the lungs. J. appl. Physiol., 1, 825.

Rodman, T., and Close, H. P. (1959). The primary hypoventilation syndrome. Amer. J. Med., 26, 808.

Resnick, M. E., Berkowitz, R. D., Fennelly, J. F., and Olivia, J. (1962). Alveolar hypoventilation due to involvement of the respiratory centre by obscure disease of the central nervous system. Ibid., 32, 208.

Rossier, P. H. and Bühlmann, A. (1954). Cor pulmonale et pathophysiologie alveolaure. Cardiologia (Basel), 25, 132.

Sarnoff, S. J., Whittenberger, J. L., and Affeldt, J. E. (1951). Hypoventilation syndrome in bulbar poliomyelitis. J. Amer. med. Ass. $147,30$.

Singer, R. B., and Hastings, A. B. (1948). An improved clinical method for the estimation of disturbances of the acid-base balance of human blood. Medicine (Baltimore), 27, 223.

Strang, L. B. (1961). Blood gas tension measurement using a mass spectrometer. J. appl. Physiol., 16, 562.

Van Slyke, D. D., and Neili, J. M. (1924). The determination of gases in blood and other solutions by vacuum extraction and manometric measurement. J. biol. Chem., 61, 523.

West, J. B., Fowler, K. T., Hugh-Jones, P., and O'Donnell, T. V. (1957a). Measurement of the ventilation-perfusion ratio inequality in the lung by the analysis of a single expirate. Clin. Sci., 16, 529. ventilation and of perfusion in the lung by the analysis of single expirates. Ibid., 16, 549.

Wilson, R. H., Borden, C. W., Ebert, R. V., Wells, H. S., and Johnson J. J. (1950). A comparison of the effect of voluntary hyperventilation in normal persons, patients with pulmonary emphysema, tilation in normal persons, patients with pulmonary emphysem.

Wright, B.M. (1955). A respiratory anemometer. J. Physiol. (Lcld.), 127, 25P. 